\title{
Boar seminal immunosuppressive fraction attenuates the leptin concentration and restores the thymus mass during pregnancy in mice
}

\author{
L Veselský, V Holáň, J Dostál ${ }^{1}$ and B Železná \\ Institute of Molecular Genetics, Academy of Sciences of the Czech Republic, 16637 Prague 6, Czech Republic \\ and ${ }^{1}$ Institute of Animal Physiology and Genetics, Academy of Sciences of the Czech Republic, 27721 Liběchov, \\ Czech Republic
}

Correspondence should be addressed to L Veselský; Email: veselsky@img.cas.cz

\begin{abstract}
The immunosuppressive fraction (ISF) of boar seminal vesicle fluid was recently demonstrated to inhibit production of $T$ helper (Th)1 cytokines and enhance production of Th2 cytokines. The present study shows the effect of the ISF on leptin concentrations in blood plasma and adipose tissue in mice during pregnancy. The ISF effect on thymus weight during pregnancy is also demonstrated. The leptin concentration in blood plasma and adipose tissue increased and remained high in the latter half of pregnancy. ISF treatment at the beginning of pregnancy significantly lowered the leptin concentration both in blood plasma and adipose tissue of pregnant mice. Thymus involution has been described previously in pregnant mice. ISF treatment compensated for the loss of thymus mass during the whole pregnancy in the ISF-treated mice. The treatment of pregnant mice with ISF did not affect pregnancy and litter size.
\end{abstract}

Reproduction (2004) 127 581-585

\section{Introduction}

Leptin is essential for fertility in rodents (Zhang et al. 1994, Chehab et al. 1996). However, Mounzich et al. (1998) found that after conception, ob/ob mice could successfully establish and maintain pregnancy in the absence of leptin. Recently, Malik et al. (2001) demonstrated that exogenous leptin is necessary for successful implantation, but not for the maintenance of pregnancy beyond 7 days in mice. Leptin may promote vascular permeability (Cao et al. 2001), a key event in the process of decidualization and implantation (Rabbani \& Rogers 2001), and directly influence the development of the embryo.

It is commonly accepted that maternal leptin concentrations are elevated during most of the pregnancy period in rats and mice and decline just prior to parturition (Kawai et al. 1997, Tomimatsu et al. 1997, Seeber et al. 2002). This is supported by the observations of Garcia et al. (2000) who found increased leptin mRNA concentrations both in placenta and maternal adipose tissues throughout gestation in the rat; it is also supported by Amico et al. (1998) who reported that placental leptin mRNA increased over the final third of rat pregnancy. However, Kawai et al. (1997) did not find expression of leptin mRNA in the rat placenta, but reported expression of leptin receptor mRNA in late gestation (Kawai et al. 1999). In mouse, leptin transcript was abundant in maternal adipose tissue, placenta and in numerous fetal tissues (Hoggard et al. 2000), but leptin did not seem to be directly associated with conceptus growth or development.

Boar seminal vesicle fluid contains immunosuppressive fraction (ISF, Dostál et al. 1995). We previously demonstrated that ISF had an immunosuppressive effect on the lymphocytes (Dostál et al. 1997). ISF inhibited mitogenstimulated proliferation of lymphocytes and attenuated production of T helper (Th) 1 cytokines but increased production of Th2 cytokines, shifting the Th1/Th2 ratio in favor of Th2 (Veselský et al. 2003). In rats with adjuvant arthritis, the ISF treatment attenuated hind-paw edema and thymus involution and inhibited both IgG production and expression of interleukin-6 (IL-6) in peritoneal macrophages (Veselský et al. 2001).

The present study used pregnant mice as a model of the elevated leptin concentration. The study was undertaken to evaluate the effect of ISF on the concentration of leptin in the blood and adipose tissue of mice during pregnancy. It has been documented that pregnancy substantially lowers the weight of thymus (Endo \& Kanayama 1998), which is linked to the expression of progesterone receptor in thymic stroma cells in pregnancy. Therefore, we followed the ISF influence on thymus weight during pregnancy. 


\section{Materials and Methods}

\section{Animals}

BALB/c female mice (12 weeks old) were housed under controlled lighting ( $12 \mathrm{~h}$ light: $12 \mathrm{~h}$ darkness) at an ambient temperature of $22-23^{\circ} \mathrm{C}$ and humidity of $35-50 \%$, with free access to food and water. They were mated overnight and the morning when the vaginal plug was found was designated as day 1 of pregnancy. The animals were bred in animal facilities of the Academy of Sciences of the Czech Republic in Prague and were treated in accordance with National Law 167/1993 on the use of laboratory animals.

\section{Isolation of ISF from seminal vesicle fluid}

The usual purification procedure was followed (Veselský et al. 2000). Briefly, $30 \mathrm{ml}$ seminal vesicle fluid (containing about $6 \mathrm{~g}$ of protein) were precipitated in $8 \%$ ethanol at $\mathrm{pH} 7.2$ and $-2.5^{\circ} \mathrm{C}$ for $1 \mathrm{~h}$. The precipitate was centrifuged $\left(3000 \mathrm{~g}, 30 \mathrm{~min}, 4^{\circ} \mathrm{C}\right)$, dissolved in $100 \mathrm{ml}$ water, lyophilized and dissolved in $16 \mathrm{ml}$ water. Then $8 \mathrm{ml}$ of solution were chromatographed on Sephacryl S-200 column $(2.4 \times 63 \mathrm{~cm})$ and eluted with PBS at $16.8 \mathrm{ml} / \mathrm{h}$. Fractions with immunosuppressive activity were pooled, desalted, lyophilized and dissolved in $4 \mathrm{ml}$ water. Two milliliters of the solution were applied to the Sephadex G 75 column $(1.4 \times 94 \mathrm{~cm})$ and eluted with PBS at a flow rate of $4.5 \mathrm{ml} / \mathrm{h}$. Fractions with immunosuppressive activity were lyophilized and subjected to the Biocompatible Quarternary Gradient system of HPLC (Waters, Milford, MA, USA). RP HPLC was performed using a 218 TP 54 Vydac $C_{18}$ column $(4.6 \times 250 \mathrm{~mm}, 5 \mu \mathrm{m}$ particle size $)$. A sample of $1 \mathrm{mg}$ in $1 \mathrm{ml}$ of $0.05 \%(\mathrm{v} / \mathrm{v})$ trifluoracetic acid was applied and proteins were eluted by the linear gradient of $20-50 \% \mathrm{v} / \mathrm{v}$ acetonitrile at $1 \mathrm{ml} / \mathrm{min}$ for $60 \mathrm{~min}$. Fractions with immunosuppressive activity were collected and lyophilized.

\section{Sample collection and ISF treatment}

Four experimental groups (ten mice in each time point) were established. Blood plasma, parametrial adipose tissue and thymus were obtained from decapitated animals.

Group 1 were naive virgin mice, group 2 were virgin mice that received intraperitoneally $150 \mu \mathrm{g}$ ISF in $0.1 \mathrm{ml}$ PBS for 3 days. Samples from decapitated animals were taken on days 1, 7 and 15 after the first injection of ISF.

Groups 3 and 4 were pregnant mice. Group 3 remained untreated, group 4 was injected intraperitoneally with $150 \mu \mathrm{g}$ ISF in $0.1 \mathrm{ml}$ PBS on days 1, 2 and 3 of pregnancy. Samples from decapitated animals were obtained on days $7,10,13,15,17$ and 19 of pregnancy and day 23 (postpartum). Blood plasma and adipose tissue were frozen and stored at $-20^{\circ} \mathrm{C}$ until use.

\section{Adipose tissue extraction}

For determination of the leptin concentration in adipose tissue, parametrial adipose tissue was collected from pregnant animals and virgin mice. The adipose tissue was

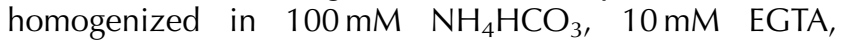
$10 \mathrm{mM}$ EDTA, pH 9.3 for $1 \mathrm{~min}$. The homogenate was centrifuged at $5000 \mathrm{~g}$ for $20 \mathrm{~min}$ and the supernatant was used for the test. The leptin concentration in adipose tissue was expressed in nanograms per gram of wet tissue.

\section{Leptin ELISA}

Leptin concentrations in blood plasma and adipose tissue extract were determined by the ELISA kit using the procedure described by the manufacturer (Crystal Chem. Inc., Chicago, IL, USA).

\section{Statistical analysis}

Values represent the means \pm S.D.

Data were analyzed for homogenity of variance by ANOVA test. Subsequent significance of the differences between experimental and control groups was analyzed using Student's $t$-test.

\section{Results}

\section{Leptin levels in blood plasma and adipose tissue of pregnant and virgin mice and the effect of ISF on leptin concentration}

From day 10 of pregnancy to day 23 (postpartum), the blood plasma leptin level was significantly higher than that in virgin mice $(P<0.01)$. On day 15 , the leptin level in pregnant mice $(64.7 \pm 11.1 \mathrm{ng} / \mathrm{ml})$ was approximately 7 times higher than that in virgin mice $(8.4 \pm 2.4 \mathrm{ng} / \mathrm{ml}) \quad$ or $\quad$ ISF-treated virgin mice $(9.7 \pm 2.4 \mathrm{ng} / \mathrm{ml})$. After day 19 of pregnancy, the blood plasma leptin level declined sharply (Fig. 1).

ISF applied for the first 3 days of pregnancy significantly lowered the leptin concentration in blood plasma (from $64.7 \pm 11.1 \mathrm{ng} / \mathrm{ml}$ in pregnant mice to $12.6 \pm 7 \mathrm{ng} / \mathrm{ml}$ in pregnant mice treated with ISF as found out on day 15 of pregnancy). After that the leptin concentration in ISF-treated mice increased rapidly and exceeded that of pregnant untreated mice (Fig. 1).

The leptin concentration in adipose tissue of pregnant animals increased after day 13 of pregnancy and peaked on day 15 (41.3 $\pm 8.4 \mathrm{ng} / \mathrm{g}$ wet tissue), when it was about 4 times higher than that of naive virgin or ISF-treated virgin mice $(9 \pm 3.3$ and $10.4 \pm 2.8 \mathrm{ng} / \mathrm{g}$ wet tissue respectively). After that, it decreased linearly and on day 23 (postpartum) reached the values of naive virgin or ISF-treated virgin mice (Fig. 2).

ISF applied in the first 3 days of pregnancy significantly decreased the leptin level in adipose tissue (from $41.3 \pm 8.4 \mathrm{ng} / \mathrm{g}$ wet tissue in pregnant mice to $14 \pm 6 \mathrm{ng} / \mathrm{g}$ wet tissue in pregnant mice treated with ISF, 


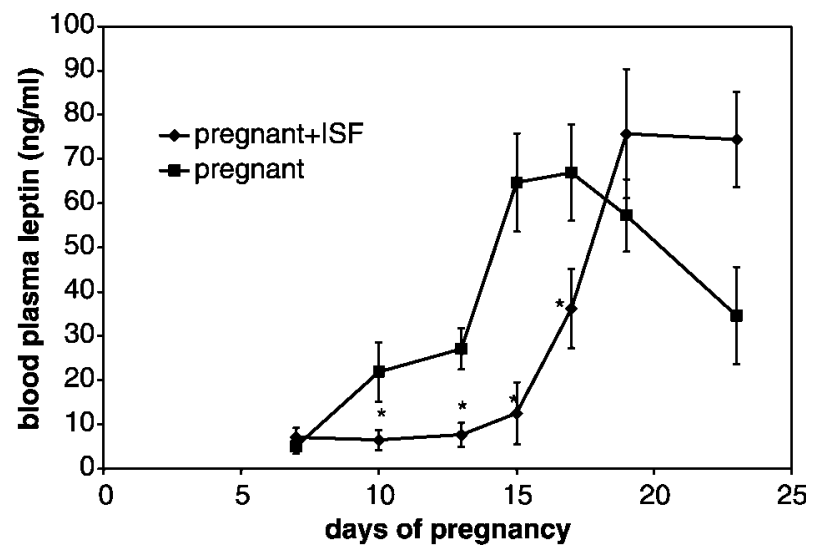

Figure 1 ISF maintained a low level of plasma leptin until 15 day of pregnancy. Blood was collected from pregnant mice $(\mathbf{\square})$ and from pregnant mice treated with ISF $(\bullet)$ on indicated days and the plasma leptin concentration was assessed by sandwich ELISA. Leptin plasma concentrations of virgin mice were $8.5 \pm 2.8$ and $8.4 \pm 2.4 \mathrm{ng} / \mathrm{ml}$ on days 7 and 15 respectively. Leptin plasma concentrations of ISF-treated virgin mice were $10.8 \pm 1.8$ and $9.7 \pm 2.4 \mathrm{ng} / \mathrm{ml}$ on days 7 and 15 respectively. Values represent the means \pm S.D. ${ }^{*} P<0.01$ versus pregnant mice not treated with ISF.

as found out on day 15 of pregnancy). After that the leptin concentration increased and reached that of pregnant untreated mice on day 19 of pregnancy (Fig. 2).

In virgin mice, ISF did not significantly affect the leptin level in blood plasma and adipose tissue.

\section{Thymus weight of pregnant and virgin mice and the effect of ISF on thymus weight during pregnancy}

The weight of thymus of virgin mice was not significantly influenced by ISF treatment $(40.7 \pm 10.1$ and

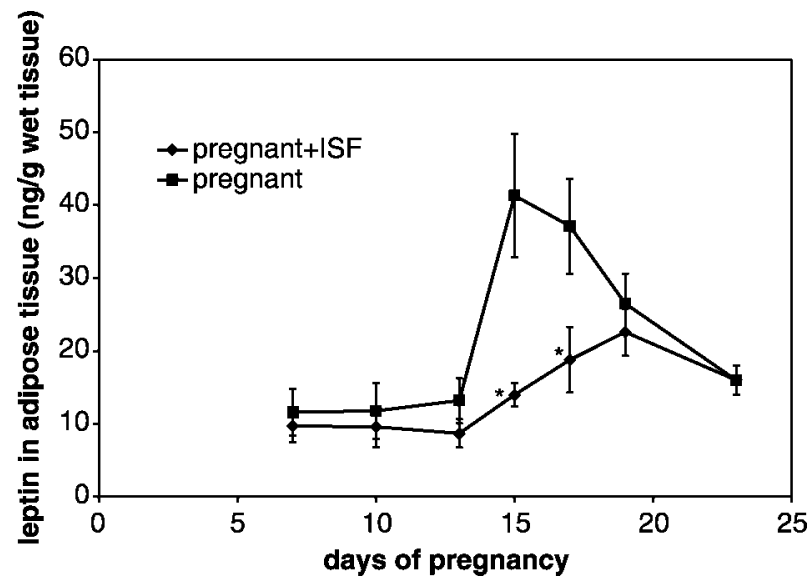

Figure 2 ISF maintained a low concentration of leptin in adipose tissue during pregnancy. Tissues were collected from pregnant mice (ם) and from pregnant mice treated with ISF $(\bullet)$ on indicated days, homogenized in extraction buffer and leptin concentration determined by sandwich ELISA. Leptin concentrations in adipose tissue of virgin mice were $9.5 \pm 3.1$ and $9.0 \pm 3.3 \mathrm{ng} / \mathrm{g}$ wet tissue on days 7 and 15 respectively. Leptin concentrations in adipose tissue of ISF-treated virgin mice were $9.3 \pm 3.0$ and $10.4 \pm 2.8 \mathrm{ng} / \mathrm{g}$ wet tissue on days 7 and 15 respectively. Values represent the means \pm S.D. ${ }^{*} P<0.01$ versus pregnant mice not treated with ISF.
$35.7 \pm 7.0 \mathrm{mg}$ respectively on day 7 after the beginning of the treatment). The thymus weight was substantially lowered by pregnancy: from day 7 of pregnancy it decreased linearly and after delivery reached a minimum value of $10 \pm 2.5 \mathrm{mg}$ on day 23 (postpartum). The loss of thymus mass in pregnant mice was totally prevented by the ISF treatment until day 17 of pregnancy; then it was prevented only partially, but significantly $(26.4 \pm 5.8 \mathrm{mg}$ in ISF-treated and $10 \pm 2.5 \mathrm{mg}$ in untreated postpartum mice; Fig. 3).

\section{Effect of ISF treatment on litter size}

ISF decreased leptin levels in both plasma and adipose tissue and totally prevented thymus involution until day 17 of pregnancy. In addition, it significantly decreased the loss of thymus mass even after delivery. Regardless of all these ISF effects, we did not find any deviations from normal pregnancy, including litter size (Table 1).

\section{Discussion}

In this study, we found a substantial increase in leptin concentration both in blood plasma and adipose tissue in the latter half of mouse pregnancy; these results corresponded with previous studies in mice (Tomimatsu et al. 1997) and in rats (Kawai et al. 1997). During mouse pregnancy, OB- $R_{e}$, a soluble form of leptin receptor is secreted into the peripheral circulation, where it has been suggested that it binds leptin and prevents it from binding to a signaling form of the receptor, thereby potentiating leptin resistance (Gavrilova et al. 1997, Mounzich et al. 1998). Leptin resistance in pregnancy is believed to ensure the demands of rapid fetal growth are met in the latter period of pregnancy (Henson \& Castracane 2000).

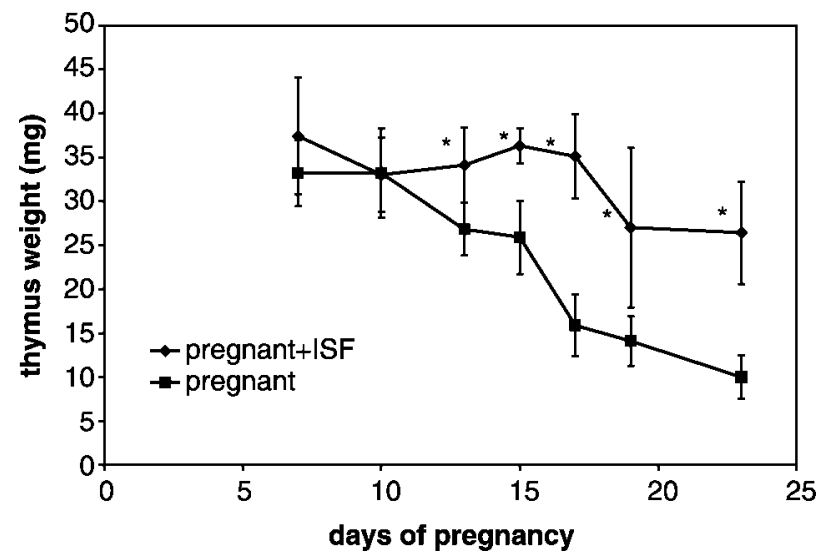

Figure 3 The loss of thymus mass observed in pregnant mice was significantly recovered by treatment with ISF. In pregnant mice (ם) and in pregnant mice treated with ISF ( $)$ the weight of thymus was assessed on the days indicated. Thymus weights of virgin mice were $36.2 \pm 11.7$ and $40.7 \pm 10.1 \mathrm{mg}$ on days 7 and 15 respectively. Thymus weights of virgin mice treated with ISF were $33.4 \pm 5.7$ and $36.0 \pm 7.0 \mathrm{mg}$ on days 7 and 15 respectively. Values represent the means \pm S.D. ${ }^{*} P<0.01$ versus pregnant mice not treated with ISF. 
Table 1 Effect of decreased leptin level and increased thymus weight on litter size in mice. Values represent the means \pm S.D. for ten mice decapitated in one time interval.

\begin{tabular}{lcc}
\hline Days of pregnancy & Pregnant + ISF & Pregnant \\
\hline 10 & $5.2 \pm 1.5$ & $4.9 \pm 1.5$ \\
13 & $5.9 \pm 1.6$ & $5.6 \pm 1.6$ \\
15 & $5.2 \pm 1.4$ & $6.5 \pm 1.5$ \\
17 & $5.1 \pm 1.9$ & $5.1 \pm 1.4$ \\
19 & $6.2 \pm 0.8$ & $6.0 \pm 2.0$ \\
23 (postpartum) & $5.4 \pm 1.7$ & $5.0 \pm 2.0$ \\
\hline
\end{tabular}

ISF, immunosuppressive fraction of boar seminal plasma.

Although ISF caused a decrease in leptin concentration and attenuation of thymus involution until day 17 of pregnancy, it did not hamper implantation and development of the fetuses. Our previous results indicated that ISF adsorbed on the zona pellucida of porcine or murine oocytes had no effect on the embryo and fetus development in vitro or in vivo (Veselský et al. 1991). This was confirmed by the fact that monoclonal antibodies to ISF did not affect the ability of boar spermatozoa to penetrate porcine zona pellucida (Veselský et al. 1993).

We found that a short-term treatment with ISF after immunization led only to a temporary suppression of immune response but not to a permanent tolerance to antigens (Dostál et al. 1997). We observed that ISF persisted in circulation for 15 days (Dostál et al. 1995). This could explain the fact that in this study, after day 15 of pregnancy and after clearing of ISF from the circulation, leptin concentration increased.

We suppose that the ISF-induced decrease in leptin concentration is responsible for the inhibition of thymus involution. In normal pregnancy, the Th2 immune response with preferential production of IL-4, IL-5 and IL10 cytokines occurs while Th1 cytokines such as interferon (IFN)- $\gamma$ and IL-2 or tumor necrosis factor (TNF)- $\alpha$ are down-regulated. If the cytokine pattern of the normal pregnancy was shifted, pregnancy failed both in rodents and humans (Tangri \& Raghupathy 1993, Hill et al. 1995, Raghupathy 2001). However, new data demonstrated that neither maternal nor fetal production of Th2 cytokines IL4 and IL-10 was crucial for the successful completion of pregnancy in mice (Svenson et al. 2001). The effect of cytokines on leptin production may be more complicated. It has been shown that TNF- $\alpha$ significantly inhibited leptin production by cultured adipocytes and pre-adipocytes differentiated in vitro (Fawcett et al. 2000). In vivo TNF- $\alpha$ and IL-1 $\alpha$ increased serum leptin concentration in humans (Janik et al. 1997, Zumbach et al. 1997). In vivo cytokineinduced release of leptin into serum may not result from a direct effect of the cytokines on the adipose tissue and we do not suppose that the decrease of leptin concentration in this study is caused by an ISF effect on the Th1/Th2 pattern. Leptin secretion both in vivo and in vitro is potently stimulated by glucocorticoids (Fried et al. 2000) and $11 \beta$-hydroxysteroid dehydrogenase has been recognized as a major modulator of local glucocorticoid concentration in adipose tissue (Sandeep \& Walker 2001). Local glucocorticoid concentrations may therefore play an important role in the regulation of leptin synthesis and release. Recently we documented that high concentrations of corticosterone in arthritic rats were suppressed by ISF treatment (Veselský et al. 2001). We suggest that the ISFinduced inhibition of glucocorticoid synthesis also inhibits leptin release from adipose tissue.

We did not record any effect of the ISF-blocked leptin secretion, both in plasma and adipose tissue, on fetal weight, survival of neonatal descendants or the number of neonatals. The weight of fetuses depended on the number of fetuses implanted in the uterus but not on the leptin concentration: the higher the number of fetuses in the uterus, the lower their individual weights. We did not find any malformation or deviation from normal physiological development of descendants caused by ISF-induced leptin reduction.

In this study, ISF lowered the concentration of leptin in blood plasma and adipose tissue in the first period of pregnancy and prevented thymus involution during pregnancy. ISF did not affect pregnancy, delivery or litter size, confirming that leptin is not essential to the maintenance of pregnancy in mice.

\section{Acknowledgements}

We thank Mrs M Hošková and Mrs L Koberová for their excellent technical assistance. This work was supported by grant 303/01/0615 from the Grant Agency of the Czech Republic and by grant NI/6883-3 from the Grant Agency of the Ministry of Health of the Czech Republic.

\section{References}

Amico JA, Thomas AT, Crowley RS \& Burmeister LA 1998 Concentrations of leptin in the serum of pregnant, lactating and cycling rats and of leptin messenger ribonucleic acid in rat placental tissue. Life Sciences 63 1387-1395.

Cao R, Brakenhielm E, Wahlestedt C, Thyberg J \& Cao Y 2001 Leptin induces vascular permeability and synergistically stimulates angiogenesis with FGF-2 and VEGF. PNAS 98 6390-6395.

Chehab FF, Lim ME \& Lu E 1996 Correction of the sterility defect in homozygous obese female mice by treatment with the human recombinant leptin. Nature Genetics 12 318-320.

Dostál J, Veselský L, Drahorád J \& Jonáková V 1995 Immunosuppressive effect induced by intraperitoneal and rectal administration of boar seminal immunosuppressive factor. Biology of Reproduction 52 1209-1214.

Dostál J, Veselský L, Marounek M, Železná B \& Jonáková V 1997 Inhibition of bacterial and boar epididymal sperm immunogenicity by boar seminal immunosuppressive component in mice. Journal of Reproduction and Fertility 111 135-141.

Endo T \& Kanayama K 1998 Changes in the weight of the thymus after birth and in pregnancy in mice. Research Communications in Molecular Pathology and Pharmacology 101 307-310.

Fawcett RL, Waechter AS, Williams LB, Zhang P, Louie R, Jones R, Inman M, Huse J \& Considine RV 2000 Tumor necrosis factor- $\alpha$ inhibits leptin production in subcutaneous and omental adipocytes from morbidly obese humans. Journal of Clinical Endocrinology and Metabolism 85 530-535. 
Fried SK, Ricci MR, Russell CD \& Laferrere B 2000 Regulation of leptin production in humans. Journal of Nutrition $\mathbf{1 3 0}$ 3127S-3131S

Garcia MD, Casanueva FF, Dieguez C \& Senaris RM 2000 Gestational profile of leptin messenger ribonucleic acid (mRNA) content in the placenta and adipose tissue in the rat, and regulation of the mRNA levels of the leptin receptor subtypes in the hypothalamus during pregnancy and lactation. Biology of Reproduction 62 698-703.

Gavrilova O, Barr V, Marcus-Samuels B \& Reitman M 1997 Hyperleptinemia of pregnancy associated with appearance of a circulating form of the leptin receptor. Journal of Biological Chemistry 272 30546-30551.

Henson MC \& Castracane VD 2000 Leptin in pregnancy. Biology of Reproduction 63 1219-1228.

Hill JA, Polgar K \& Anderson DJ 1995 T-helper 1-type immunity to trophoblast in women with recurrent spontaneous abortion. Journal of American Medical Association 273 1933-1936.

Hoggard N, Hunter L, Lea RG, Trayhurn P \& Mercer JG 2000 Ontogeny of the expression of leptin and its receptor in the murine fetus and placenta. British Journal of Nutrition 83 317-326.

Janik JE, Curti BD, Considine RV, Roger HC, Powers GC, Alvord WG, Smith JW II, Gause BL \& Kopp WC 1997 Interleukin 1 alpha increases serum leptin concentrations in humans. Journal of Clinical Endocrinology and Metabolism 82 3084-3086.

Kawai M, Yamaguchi M, Murakami T, Shima M, Murata Y \& Kishi K 1997 The placenta is not main source of leptin production in pregnant rat: gestational profile of leptin in plasma and adipose tissue. Biochemical and Biophysical Research Communications 240 798-802.

Kawai M, Murakami T, Otani S, Shima K, Yamaguchi M \& Kishi K 1999 Colocalization of leptin receptor (OB-R) mRNA and placental lactogen-II in rat trophoblast cells: gestational profile of OB-R mRNA expression in placentae. Biochemical and Biophysical Research Communications 257 425-430.

Malik NM, Carter ND, Murray JF, Scaramuzzi RJ, Wilson CA \& Stock MJ 2001 Leptin requirement for conception, implantation and gestation in the mouse. Endocrinology 142 5198-5202.

Mounzich K, Qin J, Ewart-Toland A \& Chehab FF 1998 Leptin is not necessary for gestation and parturition but regulates maternal nutrition via a leptin resistance state. Endocrinology 139 5259-5262.

Rabbani ML \& Rogers PA 2001 Role of vascular endothelial growth factor in endometrial vascular events before implantation in rats. Reproduction 122 85-90.

Raghupathy R 2001 Pregnancy: success and failure within Th1/Th2/Th3 paradigm. Seminars in Immunology 13 219-227.

Sandeep TC \& Walker BR 2001 Pathophysiology of modulation of local glucocorticoid levels by 11 beta-hydroxysteroid dehydrogenases. Trends in Endocrinology and Metabolism 12 446-453.
Seeber RM, Smith JT \& Waddell BJ 2002 Plasma leptin-binding activity and hypothalamic leptin receptor expression during pregnancy and lactation in the rat. Biology of Reproduction $\mathbf{6 6}$ $1762-1767$.

Svensson L, Arvola M, Sällström MA, Holmdahl R \& Mattsson R 2001 The Th2 cytokines IL-4 and IL-10 are not crucial for the completion of allogenic pregnancy in mice. Journal of Reproductive Immunology 51 3-7.

Tangri S \& Raghupathy R 1993 Expression of cytokines in placentas of mice undergoing immunologically mediated spontaneous resorptions. Biology of Reproduction 49 850-856.

Tomimatsu T, Yamaguchi $M$, Murakama T, Ogura K, Sakata $M$, Mitsuda N, Kanzaki T, Irahara H, Miyake A, Shima K, Aono T \& Murata Y 1997 Increase of mouse leptin production by adipose tissue after midpregnancy: gestational profile of serum leptin concentration. Biochemical and Biophysical Research Communications $240213-215$.

Veselský L, Dostál J, Staněk R, Procházka R \& Vinter P 1991 Lack of effect of boar seminal vesicle fluid immunosuppressor factor on embryo development. Journal of Reproductive Immunology 20 297-303.

Veselský L, Landa V, Dostál J, Běhalová E, Staněk R \& Vinter P 1993 Reactivities of monoclonal antibody directed against an immunosuppressive molecule in boar seminal plasma. Journal of Reproductive Immunology 24 187-200.

Veselský L, Jonáková V, Dostál J, Holáň V, Voburka Z, Drahorád J, Maňásková P \& Železná B 2000 Inhibition of the antibody response to rat blood transfusion antigens in mice by boar seminal immunosuppressive fraction. American Journal of Reproductive Immunology 44 325-335.

Veselský L, Zelezná B, Dostál J, Stančiková M, Švik K, Rokyta R \& Jurčovičová J 2001 Suppression of adjuvant arthritis in rats by boar seminal immunosuppressive fraction. Clinical and Experimental Rheumatology 19 153-158.

Veselský L, Holáň V, Zajícová A, Dostál J \& Železná B 2003 Effect of boar seminal immunosuppressive fraction on production of cytokines by concanavalin A-stimulated spleen cells and on proliferation of B lymphoma cell lines. American Journal of Reproductive Immunology 49 249-254.

Zhang Y, Proenca R, Maffei M, Barone M, Leopold L \& Friedman JM 1994 Positional cloning of the mouse obese gene and its human homologue. Nature 372 425-432.

Zumbach MS, Boehme MW, Wahl P, Stremmel W, Ziegler R \& Nawroth PP 1997 Tumor necrosis factor increases leptin serum levels in humans. Journal of Clinical Endocrinology and Metabolism 82 4080-4082.

Received 17 September 2003

First decision 27 October 2003

Accepted 29 January 2004 